(C)Borgis

*Tomasz Derkowski ${ }^{1}$, Sylweriusz Kosinski², Tomasz Sanak ${ }^{3}$, Paweł Podsiadlo1,4, Daniel Celinski ${ }^{1,5}$,

Robert Galazkowski ${ }^{1,5}$, Tomasz Darocha ${ }^{1,6}$

\title{
Post-traumatic hypothermia in the pre-hospital period - diagnosis and treatment
}

\section{Hipotermia pourazowa w okresie przedszpitalnym - rozpoznanie i leczenie}

${ }^{1}$ Polish Air Medical Rescue, Warsaw, Poland

${ }^{2}$ Department of Emergency Medical Services, Collegium Medicum Jagiellonian University, Cracow, Poland

${ }^{3}$ Department of Disaster and Emergency Medicine, Collegium Medicum Jagiellonian University, Cracow, Poland

${ }^{4}$ Polish Society for Mountain Medicine and Rescue, Szczyrk, Poland

${ }^{5}$ Department of Emergency Medical Services, Medical University of Warsaw, Poland

${ }^{6}$ Department of Anaesthesiology and Intensive Therapy, Medical University of Silesia, Katowice, Poland

\section{Keywords}

post-traumatic hypothermia, thermal insulation, shock

\section{Słowa kluczowe}

hipotermia pourazowa, termoizolacja, wstrząs

\section{Conflict of interest \\ Konflikt interesów}

None

Brak konfliktu interesów

\section{Address/adres:}

*Tomasz Derkowski

Lotnicze Pogotowie Ratunkowe

ul. Księżycowa 5, 01-934 Warszawa

tel. +48 605-885-365

t.derkowski@lpr.com.pl

\section{Su m m a ry}

Implications of post-traumatic hypothermia are known for over four decades however general awareness of such occurrence is still low.

Post-traumatic hypothermia is a risk factor for severe complications and death of patients with serious injuries. Medical treatment in perioperative period should be directed towards the prompt cessation of patient exposure to adverse weather conditions, inhibition of heat loss by appropriate thermal insulation, haemorrhage control, avoidance of excessive administration of fluids and quick transfer to a hospital in appropriately prepared means of transport.

Hypothermia awareness, preventative tasks and coordination of action at each stage of the rescue is crucial.

\section{Streszczenie}

Konsekwencje hipotermii w okresie pourazowym są znane od ponad czterech dekad, ale świadomość problemu jest nadal niska. Hipotermia pourazowa jest czynnikiem ryzyka groźnych powikłań i zgonu u chorych z ciężkimi obrażeniami ciała. Postępowanie medyczne w okresie przedszpitalnym powinno być ukierunkowane na jak najszybsze przerwanie ekspozycji na niekorzystne warunki środowiska, zahamowanie utraty ciepła poprzez adekwatną izolację termiczną, tamowanie krwotoków, unikanie masywnych przetoczeń płynów i jak najszybszy transport do szpitala w odpowiednio przygotowanym środku transportu. Niezwykle istotne są świadomość problemu, prewencja i odpowiednia koordynacja działań na każdym etapie leczenia.

\section{INTRODUCTION}

In accordance with the ATLS committee, post-traumatic hypothermia can be diagnosed at the central temperature below $36^{\circ} \mathrm{C}(1)$. Further stages and posttraumatic hypothermia classification is shown in the table $1(2,3)$. Certain scientific literature acknowledges hypothermia at $35^{\circ} \mathrm{C}$, however in Poland the ATLS definition is considered correct due to the impact of post-traumatic period as well as prevention role in hypothermia.

Tab. 1. Post-traumatic hypothermia classification

\begin{tabular}{|l|c|}
\hline \multicolumn{1}{|c|}{ Classification } & Temperature range \\
\hline Mild & $36-34^{\circ} \mathrm{C}$ \\
\hline Moderate & $34-32^{\circ} \mathrm{C}$ \\
\hline Severe & $<32^{\circ} \mathrm{C}$ \\
\hline
\end{tabular}

The "post-traumatic hypothermia" term have been introduced in the 80's of $20^{\text {th }}$ century (3-5). Commonly, and alongside with acidosis and coagulopathy, have been known as "deadly triad". However, nowadays, hypothermia is being recognized as a standalone factor in severe injury complications. Indeed, the knowledge around this matter is confined among certain medical personnel groups only (6).

\section{REVIEW}

\section{Pathophysiology}

Both hypothermia types - due to cold exposure (also known as accidental) as well as post-traumatic - results from negative thermal balance, i.e. higher heat loss than its production. Ways of heat loss and its meaning in post-traumatic hypothermia have been described in table 2. 
Tab. 2. Major means of heat loss in human body

\begin{tabular}{|l|l|}
\hline Means of heat loss & \multicolumn{1}{c|}{ Description and meaning } \\
\hline Conduction & $\begin{array}{l}\text { Heat transfer via direct contact, such as body adherence to lower temperature surface - concrete (fig. 1), ground, spinal } \\
\text { board. Major heat loss is caused by body immersion in water. Wet clothes speed up the heat loss. }\end{array}$ \\
\hline Convection & $\begin{array}{l}\text { Heat transfer from the body surface to the surrounding air. Convectional heat loss is further escalated by the air move- } \\
\text { ment, such as wind, draught or open window in the ambulance. }\end{array}$ \\
\hline Radiation & $\begin{array}{l}\text { Energy transfer in form of radiation within the infrared band. The energy is being emitted by warmer objects and absorbed } \\
\text { by colder ones. The lower surface temperature, the lower amount of heat is being transferred. Usually the radiation is one } \\
\text { of ways of the heat loss, however in case of insulation or radiators, radiation can allow to create the heat gain. }\end{array}$ \\
\hline Vaporization & $\begin{array}{l}\text { Loss of the heat that allows needed for vaporization of the moisture from the skin surface. In hypothermia such process } \\
\text { takes place under sealed, moisture-proof clothes and covers. }\end{array}$ \\
\hline Breathing & $\begin{array}{l}\text { Approximately 10\% of the whole heat loss takes place via airways (convection and moisture vaporization from mucous } \\
\text { membrane). }\end{array}$ \\
\hline
\end{tabular}

\section{Epidemiology: causes and risk factors}

Among patients with body injuries as admitted to ER's, the hypothermia occurs from $1.5 \%$ to over $60 \%$ (7-11). Such huge discrepancy comes from both, various criteria as used while diagnosis as well as scientific research methodology. The main issue seems to be not so much the set temperature threshold, but the frequency and the means of its measurement. It turns out that the core temperature $(\mathrm{Ct})$ measurement, even though it should be the case, in fact it is not the routine task with patients suffering from serious injury. In German register of multi-organ injuries (DGU) the $\mathrm{Ct}$ measurement has been documented at less than $40 \%$ of patients (12). It turns out that the most serious risk factor for posttraumatic hypothermia is the nature and severity of the injury along with the existing shock $(9,13-16)$. Metabolic transition is being carried out much slower due to the limited flow of the blood within tissues. This results in limited production of the heat. The tissue hypoxia is also a natural inhibitor of muscular shiver that, in normal circumstances, provides very effective way for thermogenesis. Should you add intensified loss of the heat to the impaired heat production, it will result in a very rapid loss of the core temperature. Table 3 summarizes post-traumatic hypothermia risk factors.

Tab. 3. Post-traumatic hypothermia risk factors (according to 9, 13-19)

- Nature and severity of the injury (penetrating trauma, Injury Severity Score > 15)

- Volume and temperature of the intravenous fluid administration

- Temperature inside the transporting unit

- Age $>65$ years

- Neurological impairment (GCS < 8)

- Immobilisation (i.e. inside a vehicle)

- Head injury

- Alcohol intoxication

- Extended time between the sustained injury and the arrival at the hospital

- Endotracheal intubation

- Cold time of the year

It is worth highlighting that the exposure to the external conditions is not a predominant risk factor. In case of injury-caused hypothermia more important are both thermoregulatory and thermogenesis mechanisms. That's why the reduction of the core temperature can take place at any time throughout the year, and any weather conditions. Furthermore, significant impact on this can take place due to iatrogenic causes, such as prolonged exposure time and the transport time to the hospital (fig. 1), enormous fluid administration failure to- or application of inadequate thermal insulation (fig. 2). In addition to this, both heat loss and the reduction of the core temperature can take place in each stage between the injury and definitive treat-

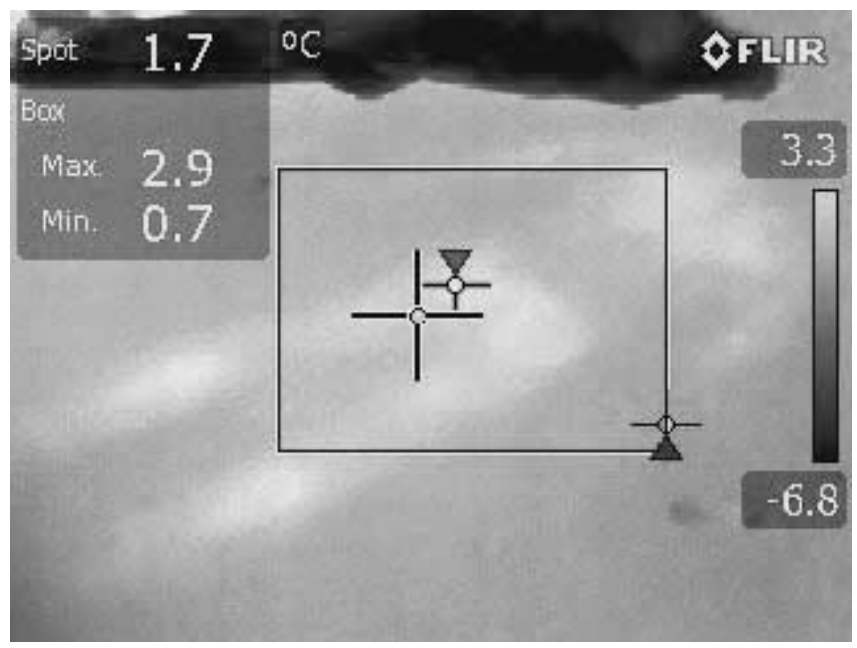

Fig. 1. Thermal trace of the human in thermography (so called "symptom of the Turin Shroud"). The picture of the concrete where the injured patient has been laid. It shows the role of conduction in heat loss of the organism. Own archive by Tomasz Sanak

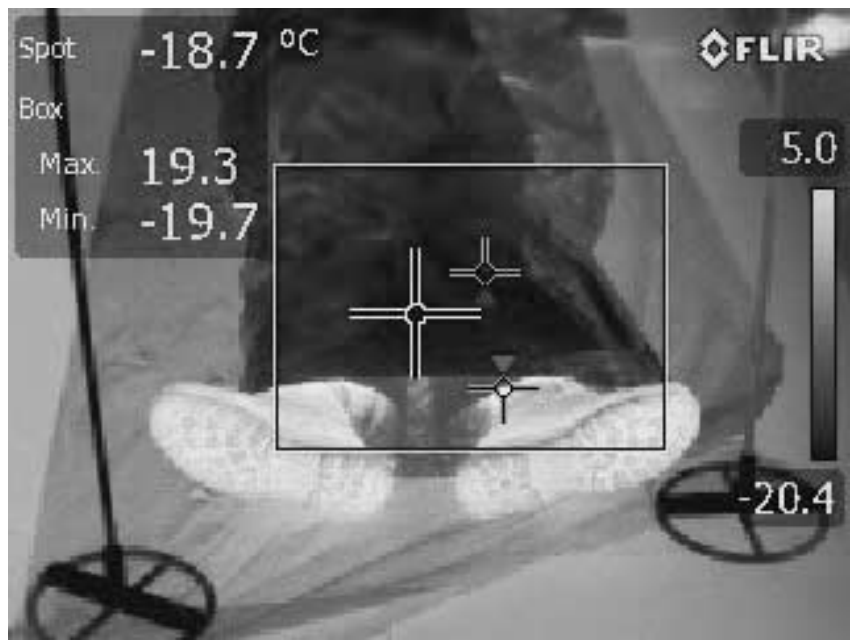

Fig. 2. Thermo-insulation escape routes leading to heat loss - picture taken with thermographic camera; light yellow color states the heat loss areas. Own archive by Tomasz Sanak 
ment of sustained injuries. Usually the loss of the core temperature - where injury took place and during the transfer - spans between $1.5-1.7^{\circ} \mathrm{C}(13,14,18)$, at the emergency unit it is approx. $0.8^{\circ} \mathrm{C}(20,21)$, and during emergency surgery approx. $1.2^{\circ} \mathrm{C}$ in first hour, with additional $0.3^{\circ} \mathrm{C}$ in further hours (22).

\section{Diagnosis}

Post-traumatic hypothermia results in the effect of body reserve depletion, and as prognosis, it is a very disturbing symptom. Its diagnosis is very hard to determine due to the fact that, alongside usual clinical symptoms, we've got additional body injuries and post-traumatic shock. Hence why Swiss Staging System as well as other systems cannot be used with patients with severe injuries. The only way of diagnosing and monitoring of the hypothermia process is ongoing temperature check. In practice however, during perioperative prehospital evaluation, core temperature checks take place very rarely. It is because both, technical reasons (lack of adequate equipment) as well as organizational reasons (often there are other priorities) (12).

It is worth mentioning that the core temperature checks with patients suffering from post-traumatic hypothermia is not as important as it is in case of an accidental hypothermia. In normal circumstances of severe hypothermia - not followed by the injury - core temperature checks "opens up doors" to extracorporeal heating, which is the most advanced and most effective form of the treatment. Unfortunately, patients with sustained severe injuries usually have absolute contraindication to heparinization that is required to upkeep the patency of extracorporeal blood circulation (23). In such case it is worth to assume that each patient with sustained severe injury is threatened by hypothermia and each patient should have applied adequate preventive methods of a heat loss.

\section{Aftermath}

Most likely hypothermia is the independent risk factor in death followed by severe injuries (24-28). With children, the risk of severe complications and a death due to post-traumatic hypothermia is further increased due to the body mass disproportion in comparison with the body surface and immature thermoregulation mechanisms. Hence why, in this group it is recommended to pay particular diagnostic alertness, and the heat loss preventions by all available means (28). Among other consequences of post-traumatic hypothermia, it is important to pay attention to increased blood loss, higher volume of intravenous fluids and blood products, longer surgery time, longer stay at the intensive care unit, longer overall hospitalization period, increased risk of organ failure, prolonged period of artificial ventilation and increased risk of sepsis as well as acute respiratory distress syndrome (ARDS) $(9,13,16,29-32)$.

Moderate and severe post-traumatic hypothermia occurs rarely, that is with approx. $5 \%$ patients with multi-organ injuries, but it can lead to even $100 \%$ of death rate $(3,33)$.
One of the most important, adverse effects of the body temperature loss in post-injury period is coagulopathy. Hypothermia affects both, directly \& indirectly the coagulation system. Hypothermia, especially in its chronic case, leads to initial dehydration, blood thickening, and increased blood viscosity. Hematocrit increases approx. $2 \%$ with the loss of each $1{ }^{\circ} \mathrm{C}$ of the body temperature. Further to this, hypothermia reduces the synthesis of prostacyclin within endothelium as well as its anti-aggregation impact on platelets. In such case, initially you may observe slight increase in hypercoagulability, however such phase doesn't appear with patients sustaining blood-loss related injuries. In its further stage, it proceeds with the inhibition of activity of pretty much all plasma factors within coagulation system as well as platelet thromboxane B2. In hypothermia, injury sustained hemorrhages can significantly - and sometimes rapidly - get intense. Blood clotting disorder can be proof to clotting factor supplementation, but it can be reversed by heating up the patient. It is believed that for clinically relevant coagulopathy, the threshold is $33^{\circ} \mathrm{C}$ of core temperature $(34,35)$.

\section{Proceedings}

Main principle while dealing with the patient is to prevent further heat loss. Outdoors, the appropriate clothing will be crucial. Appropriate heat barrier supposed to be: dry, proof, multi-layered and loose (that is not tight to the body). There are no miraculous fabrics producing perfect heat barrier. The key is to use all available goods and applying them in the above order. One of most common mistakes is applying single layer - usually isothermal metallized blanket - that either sticks to the body firmly or it is being applied in the way it creates "chimneys", allowing the heat to float out of the body (fig. 2).

You need to pay a particular attention to securing the part of the body adjoining directly to the surface, or immobilizing board. The body pressure applied to both, patient's clothing and clothing components, results in drastic deterioration of thermo-insulation characteristics and higher heat loss. This so called "conduction error" can allow a major route for heat loss with patients suffering from multi-organ injuries (unpublished materials from the course "Advanced medical treatments with patients in hypothermia" by T. Sanak). Similar effect can take place by too tight fabric adhesion. The main thermo-isolators are the static air layers, enclosed between or inside fabric layers (i.e. thick woolen blanket, natural or artificial fluff). Excessive layers' squeezing results in reducing or even eliminating air spaces, deterioration of insulating attributes of fabrics and ease of conduction.

In recently published observational study it was stated that the core temperature loss in patients with sustained multi-organ injuries at the accident scene and during the transport was marked at $1.7^{\circ} \mathrm{C}$ on average. Patients who have had one full, adequate thermoisolation applied, the temp loss was cut down to $1.1^{\circ} \mathrm{C}$ on average (18). 
You may ask if the thermo-isolation on its own, properly applied should not be supplemented by active methods of heat supply. Current experience shows that chemical heating packets, that form part of the thermoisolation sets, as well as surface electrical heating systems, improve patients' comfort and allow certain heat gain. However, it's efficiency has been proven only in mild post-traumatic hypothermia (36). It is worth mentioning that external heating can prevent shivers, and the heat gain due to shivering thermogenesis is comparable with the ones gained from external sources of heat. In cases of moderate and severe hypothermia, where shivers do not take place, active external heating can be the only way to maintain positive thermal balance. This is especially vital in prolonged transport in difficult terrain conditions.

There is no scientific research evidence confirming this thesis. Convection systems (warm air inflow to blanket-type coating) have been proved useful. There are mobile versions of such equipment, made for ambulance use, however in reality these are rarely used in pre-hospital phase (14). Bearing in mind that ambulance teams act in relatively short period of time at the incident scene ("load and go procedure") as well as short period of time needed to transport the patient to the hospital, it makes sense to say that the following basic activities are most important from patient's perspective.

Initial haemorrhage control, restricted administration of unheated liquids, quick evacuation in properly heated ambulance, and correct and adequate to the circumstances thermal insulation. From the practical point of view, it is worth mentioning of analgosedation (i.e. opioids, benzodiazepines, barbiturates) that may have a negative impact on thermoregulation processes and allow heat loss. With patients suffering from injuries, correct analgesia is imperative from both medical and ethical point of view, therefore we should not restrict it. You have to bear in mind, however, that patients on cold drugs affecting cold protection reflexes have to be extremely well protected from the heat loss.

At the pre-hospital phase there is a risk of both drugs and equipment exposure to adverse weather conditions. The ambulance mattress temperature usually can span between $22.3^{\circ} \mathrm{C}$ and $+8.4^{\circ} \mathrm{C}$ (37). Intravenous fluids transfused at hypothermia cool down its way through non-insulated part of the transfusion set. The use of liquid warmers in pre-hospital phase is not a common practice. It was proved that crystalloid infusion at the temperature of $20^{\circ} \mathrm{C}$ and the dose of $53 \mathrm{ml} /$ $\mathrm{kg}$ have lowered the core temperature at $1^{\circ} \mathrm{C}$ on average (38). In low outdoor temperature (especially during winter time) administered fluids are cooling off very quickly and can lead to the hypothermia. On the other hand, it is worth mentioning that, nowadays, heating up of intravenous liquids is not considered as a heating method, but rather preventative action against temperature loss.
In such case, bearing in mind current concepts of limitation of fluids' volume transfused in pre-hospital processes, the issue of the correct temperature of infusion fluids is being regarded less important (39).

At the figure 3 you can see the procedure algorithm with injured patients, based on Perlman (7).

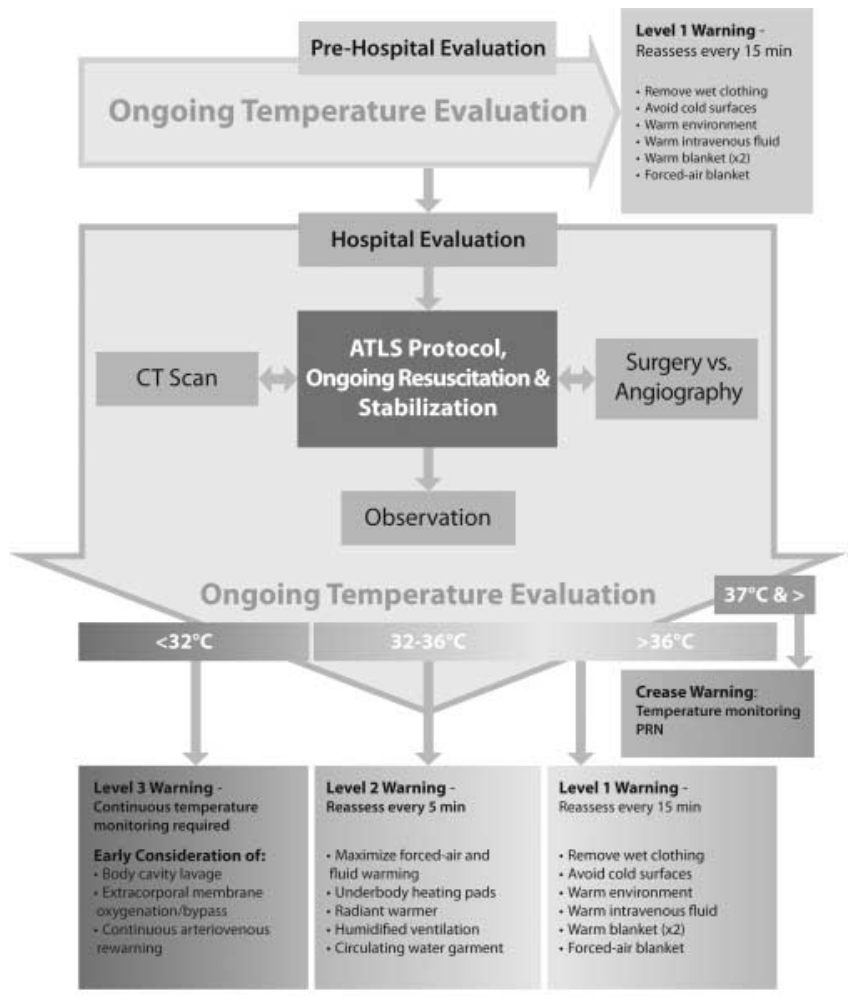

EVIDENCE-BASED WARMING STRATEGIES IN TRAUMA

Fig. 3. Recommended algorithm for injured patients as based on Perlman (7)

Recent literature stresses the importance of coordinating actions and constant, high quality preventative and therapeutic measures in connection with temperature control (so called "warm" chain of survival) (40). All links within that chain needs to be properly aware and prepared to action. This applies to the witness of the incident, dispatcher (switchboard operator), medical ambulance team, ER personnel, diagnosis labs (i.e. computer tomography), operating theatre and intensive care unit.

\section{CONCLUSIONS}

Post-traumatic hypothermia is a risk factor for severe complications and the death among patients with severe body injuries. Medical management in pre-hospital period supposed to be focused on possibly quickest patient removal from adverse environmental conditions, prevention from heat loss through the adequate thermal insulation, stopping the hemorrhage, avoidance of bulk intravenous fluid transfusion, and as quickest transfer to the hospital as possible, in adequate mean of transport. Extremely crucial is the awareness of the issue, proper prevention and adequate coordination of tasks at each and every stage of the medical treatment. 


\section{BIBLIOGRAPHY}

1. American College of Surgeons: Advanced Trauma Life Support. $7^{\text {th }}$ ed. American College of Surgeons, Chicago 2004: 240-241.

2. Kortbeek JB, AI Turki SA, Ali J et al.: Advanced trauma life support, the evidence for change. J Trauma 2008; 64(6): 1638-1650.

3. Jurkovich GJ, Greiser WB, Luterman A et al.: Hypothermia in trauma victims: an ominous predictor of survival. J Trauma 1987; 27(9): 10191024.

4. Yates DW, Little RA: Accidental hypothermia. Resuscitation 1979; 7(1) 59-67.

5. Luna GK, Maier RV, Pavlin EG et al.: Incidence and effect of hypothermia in seriously injured. J Trauma 1987; 27(9): 1014-1018.

6. Podsiadło P: Praca doktorska „Ocena skuteczności platformy e-learningowej jako formy edukacji personelu systemu ratownictwa medycznego w zakresie hipotermii”. Lublin 2017.

7. Perlman $\mathrm{R}$, Callum J, Laflamme $\mathrm{C}$ et al.: A recommended early goal-directed management guideline for the prevention of hypothermia-related transfusion, morbidity, and mortality in severely injured trauma patients. Crit Care 2016; 20(1): 107

8. Rutherford EJ, Fusco MA, Nunn CR et al.: Hypothermia in critically ill trauma patients. Injury 1998; 29(8): 605-608.

9. Martin RS, Kilgo PD, Miller PR et al.: Injury-associated hypothermia: an analysis of the 2004 national trauma databank. Shock 2005; 24(2): 114-118.

10. Shafi S, Elliott AC, Gentilello L: Is hypothermia simply a marker of shock and injury severity or an independent risk factor for mortality in trauma patients? Analysis of a large national trauma registry. J Trauma 2005; 59(5): 1081-1085

11. Wang HE, Callaway CW, Peitzman $A B$ et al.: Admission hypothermia and outcome after major trauma. Crit Care Med 2005; 33(6): 1296-1301.

12. Weuster M, Brück A, Lippross S et al.: Epidemiology of accidental hypothermia in polytrauma patients: An analysis of 15,230 patients of the TraumaRegister DGU. J Trauma Acute Care Surg 2016; 81(5): 905-912.

13. Arthurs Z, Cuadrado D, Beekley $A$ et al.: The impact of hypothermia on trauma care at the 31st combat support hospital. Am J Surg 2006; 191(5): 610-614.

14. Lapostolle, Sebbah JL, Couvreur J et al.: Risk factors for onset of hypothermia in trauma victims: the HypoTraum study. Crit Care 2012; 16(4) R142.

15. Ireland S, Endacott $\mathrm{R}$, Cameron $\mathrm{P}$ et al.: The incidence and significance of accidental hypothermia in major trauma - a prospective observational study. Resuscitation 2011; 82(3): 300-306.

16. Trentzsch H, Huber-Wagner S, Hildebrand F et al.: Hypothermia for prediction of death in severely injured blunt trauma patients. Shock 2012; 37(2): 131-139.

17. Søreide K: Clinical and translational aspects of hypothermia in major trauma patients: from pathophysiology to prevention, prognosis and potential preservation. Injury 2014; 45(4): 647-654.

18. Eidstuen SC, Uleberg O, Vangberg G: When do trauma patients lose temperature? A prospective observational study. Acta Anaestesiol Scand 2018; 62(3): 384-393.

19. Bennett BL, Holcomb JB: Battlefield Trauma-Induced Hypothermia: Transitioning the Preferred Method of Casualty Rewarming. Wilderness Environ Med 2017; 28(2S): S82-S89.

20. Gregory JS, Flancbaum L, Townsend MC et al.: Incidence and timing of hypothermia in trauma patients undergoing operations. J Trauma 1991 31(6): 795-798.
21. Bernabei AF, Levison MA, Bender JS: The effects of hypothermia and injury severity on blood loss during trauma laparotomy. J Trauma 1992; 33(6): 835-839.

22. Kurz A, Sessler DI, Christensen $R$ et al.: Heat balance and distribution during the core-temperature plateau in anesthetized humans. Anesthesiology 1995; 83(3): 491-499.

23. Arlt M, Philipp A, Voelkel $\mathrm{S}$ et al.: Extracorporeal membrane oxygenation in severe trauma patients with bleeding shock. Resuscitation 2010; 81(7): 804-809.

24. Hildebrand F, Probst C, Frink M et al.: Importance of hypothermia in multiple trauma patients. Unfallchirurg 2009; 112(11): 959-964.

25. Mommsen $\mathrm{P}$, Zeckey $\mathrm{C}$, Frink $\mathrm{M}$ et al.: Accidental hypothermia in multiple trauma patients. Zentralbl Chir 2012; 137(3): 264-269.

26. Mommsen $\mathrm{P}$, Andruszkow $\mathrm{H}$, Frömke $\mathrm{C}$ et al.: Effects of accidental hypothermia on posttraumatic complications and outcome in multiple trauma patients. Injury 2013; 44(1): 86-90.

27. Balvers K, Van der Horst M, Graumans $M$ et al.: Hypothermia as a predictor for mortality in trauma patients at admittance to the Intensive Care Unit. J Emerg Trauma Shock 2016; 9(3): 97-102.

28. Sundberg J, Estrada $C$, Jenkins $C$ et al.: Hypothermia is associated with poor outcome in pediatric trauma patients. Am J Emerg Med 2011; 29(9): 1019-1022.

29. Shafi S, Elliott AC, Gentilello L: Is hypothermia simply a marker of shock and injury severity or an independent risk factor for mortality in trauma patients? Analysis of a large national trauma registry. J Trauma 2005; 59(5): 1081-1085.

30. Beilman GJ, Blondet JJ, Nelson TR et al.: Early hypothermia in severely injured trauma patients is a significant risk factor for multiple organ dysfunction syndrome but not mortality. Ann Surg 2009; 249(5): 845-850.

31. Waibel BH, Schlitzkus LL, Newell MA et al.: Impact of hypothermia (below 36 degrees C) in the rural trauma patient. J Am Coll Surg 2009; 209(5): 580-588.

32. Waibel $\mathrm{BH}$ : Hypothermia in trauma patients: predicting the big chill. Crit Care 2012; 16(5): 155.

33. Webster B, Mellor A, Smith D: Anaesthetic priorities in pre-hospital trauma care. Anaesth Intens Care Med 2011; 12(9): 377-379.

34. Hess JR, Brohi K, Dutton RP et al.: The coagulopathy of trauma: a review of mechanisms. J Trauma 2008; 65(4): 748-754.

35. Davenport R: Pathogenesis of acute traumatic coagulopathy. Transfusion 2013; 53 (suppl. 1): 23S-27S.

36. Lundgren $\mathrm{P}$, Henriksson $\mathrm{O}$, Naredi $\mathrm{P}$ et al.: The effect of active warming in prehospital trauma care during road and air ambulance transportation-a clinical randomized trial. Scand J Trauma Resusc Emerg Med 2011; 19: 59.

37. Aléx J, Karlsson S, Saveman BI: Patient's experiences of cold exposure during ambulance care. Scand J Trauma Resusc Emerg Med 2013; 21: 44.

38. Lee SH, Kim HK, Park SC et al.: The effect of infusion rate and catheter length on the temperature of warming fluid Korean. J Anesthesiol 2010; 58(1): 31-37.

39. Cannon JW: Hemorrhagic shock. N Engl J Med 2018; 378(4): 370-379.

40. Darocha T, Kosinski S, Jarosz A et al.: The chain of survival in hypothermic circulatory arrest: encouraging preliminary results when using early identification, risk stratification and extracorporeal rewarming. Scand J Trauma Resusc Emerg Med 2016; 24: 85. 